\title{
LAND, LIVELIHOODS, AND THE DECLINE OF WORK: SOUTH AFRICAN LESSONS FOR CURRENT DEBATES
}

\author{
Ben Scully \\ Department of Sociology \\ Johns Hopkins University \\ benscully@jhu.edu
}

\begin{abstract}
This article presents a comparison of central debates in South African labor sociology in the 1970s and the contemporary era. I argue that scholars can break through impasses in current labor sociology debates by reviving attention to the land-labor-livelihood (LLL) connections that inspired theoretical advancements in the South African literature of the 1970s. After an introduction and definition of LLL connections, the paper analyzes an exemplary work of the labor literature of the 1970s, giving special attention to the way in which the LLL focus shaped the questions asked by the authors. The article proceeds to a review of central debates from the current labor literature, which focuses primarily on issues of the labor movement. It is argued that this focus on movements has limited the scope of labor scholarship, resulting in an impasse in South African labor debates. An emerging literature that renews attention to the LLL connections is proposed as a model for moving beyond this impasse. I close the article by discussing the implications for this review of South African literature for global labor scholarship.
\end{abstract}

\section{INTRODUCTION}

Michael Burawoy (2008:378) has noted the irony that over the past few decades labor scholars have increased their focus on the labor movement, despite this being a period in which unions themselves have "seemed to be in free fall." For Burawoy, this period of labor scholarship has been defined by a "public turn" away from questions about the experiences of workers in the factory and toward questions of labor as a social movement. Burawoy's argument concerns scholarship in the United States, but the observation also applies to the labor literature of South Africa and many other countries in the global South. In South Africa, over the last two decades, labor scholars have focused heavily on the labor movement, analyzing unions' political strategies (Webster and Adler 1999; Habib and Valodia 2006; Pillay 2006), their attempts to organize vulnerable workers (Webster 2006; Von Holdt and Webster 2008), and their participation in

Copyright C2012, American Sociological Association, Volume XVIII, Number 1, Pages 90-102 ISSN 1076156X 


\section{JOURNAL OF WORLD-SYSTEMS RESEARCH}

nascent international solidarity structures (Bezuidenhout 2000). Despite this intense focus on the labor movement, unions in South Africa, like those in many parts of the world, have been unable to counter the severe decline in the security of wage labor that the country's workers have experienced over the past two decades. The public turn has yet to yield theoretical or practical breakthroughs for scholars or unions in the country. Sakhela Buhlungu (2009) has gone so far as to characterize South African labor studies as a field in terminal decline.

While Buhlungu's (2009) assessment may be overly negative (and this paper will argue that it is), it shows the stark contrast between the perception of contemporary South African labor studies and labor movements as compared with those of the past. In the 1970s and 1980s South Africa was the site of one of the most dynamic labor movements of the latter part of the twentieth century, as well as a site of influential labor scholarship. Innovations associated with scholars and activists working in the country and the region, such as social movement unionism and the subsidy thesis, ${ }^{1}$ have been influential for labor unions and scholarly debates throughout the world (e.g. Wolpe 1972; Burawoy 1976; First 1983; Seidman 1994). It is this work which this article proposes as a model for advancing contemporary labor scholarship in South Africa and elsewhere, through the impasse that has led to such pessimistic prognoses as Buhlungu's. This literature was marked by an attention to what Gillian Hart and Ari Sitas (2004) have called the links between land-labor-livelihood (LLL).

\section{DEFINING THE LAND-LABOR-LIVELIHOOD CONNECTION}

What is meant by the land-labor-livelihood connection? As Hart and Sitas explained, each of these issues is generally treated in the literature on the global South as a separate "question." The "land question" includes issues of land tenure, agriculture, rural well-being, and rural development. The "labor question" includes issues of industrialization, the labor movement, and the urban middle-class. The more recent "livelihoods question" addresses informal work, household labor, and the survival strategies of the poor. Scholars who give attention to LLL connections recognize that these are not separate, but interrelated questions. For labor scholars, a focus on these connections involves a recognition that workers do not depend solely on wages for reproduction, but are embedded in networks that draw on multiple, interdependent sources of livelihood. While this is true even for workers in the global North (all workers depend to some degree on unpaid domestic labor for their reproduction), it is especially important to understanding workers in the south.

Of course, this insight is not unique to South African literature. In their introduction to the volume Creating and Transforming Households, Joan Smith and Immanuel Wallerstein argue

the appropriate operational unit for analyzing the ways in which people fit into the "labor force" is not the individual but the 'household,' defined.... as the social unit that effectively over long periods of time enables individuals, of varying ages and both sexes, to pool

\footnotetext{
${ }^{1}$ The subsidy thesis was an argument that black workers in apartheid South Africa were paid below the cost of reproduction with the difference being subsidized by family members in the rural reserves from which workers were compelled to migrate. See below for a more detailed discussion of this argument.
} 
income coming from multiple sources in order to ensure their individual and collective well-being. (1992: 12)

This insight points us to a broad conceptualization of labor, which extends beyond wages to include all sources of livelihood that contribute to social reproduction. In South Africa, like many middle income countries with relatively extensive industrialization, wages are an important component of household incomes. However, for the vast majority of South African households non-wage sources make up more than half of total income. ${ }^{2}$ These non-wage sources include subsistence production, informal market activities, government grants, and remittances (including cash and in-kind). Also, as in much of the global South, land is one of the most important resources on which households and extended kinship networks draw for livelihood. ${ }^{3}$

In a country such as South Africa, focusing labor studies exclusively on wage workers and their collective action limits scholars to only one part of workers' livelihoods. This obscures not only important factors that shape workers' well-being (or lack thereof), but even blinds scholars to factors which shape the very labor movement which is their primary object of study. The interrelation between land, livelihoods and the labor movement are illustrated by the South African literature of the 1970s and 80s that put LLL connections at the center of class and labor analysis. The next section will present a discussion of the South African literature of this era, paying special attention to the way in which LLL connections shaped the questions asked and the scope of the research.

\section{LAND, LABOR, AND LIVELIHOODS IN THE LITERATURE OF THE 1970s}

South Africa during apartheid was a place and time that produced one of the strongest examples of a scholarly literature on labor that took the land-labor-livelihood connection seriously, and developed from it fruitful theoretical and empirical analyses. There are a handful of articles and lines of debate that became well known and influential even beyond South Africa, but this characterization applies to a wide body of work that was produced by scholars working on South (and Southern) Africa during the period from the late 1960s into the early 1980s. How this focus on the land-labor-livelihood connection was developed is probably best explained by the fact that the apartheid system made these connections unavoidable for scholars. Perhaps the defining feature of the system was an attempt by the state to control, along lines of racial and ethnic categories, the mobility of labor and the sources of income to which labor-producing households had access. ${ }^{4}$

\footnotetext{
${ }^{2}$ Data from a recent nationally representative household survey (NIDS 2009) shows that wages constitute less than half of total income for households in each of the bottom seven income deciles. Wages only constitute more than two thirds of total income for households in the top two deciles. These numbers are based on the authors own calculations from the NIDS data.

${ }^{3}$ This is the case despite the fact that small scale agricultural production is relatively less significant in South Africa as compared to the rest of sub-Saharan Africa and the global South. Even when land is not used for food production, it is a source of subsistence in that it provides housing and a base from which individuals may engage in nonagricultural income-generating activities, including searching for wage labor in urban areas (see, e.g., James 2001 for a discussion on the role that land ownership plays even in supplementing urban livelihoods.)

${ }^{4}$ Ownership of land or business by Black South Africans was restricted outside of designated "homelands." Black South Africans were prevented from seeking work except through a tightly controlled labor market aimed at keeping
} 


\section{JOURNAL OF WORLD-SYSTEMS RESEARCH}

Analyzing the role of labor in this system, scholars of South and Southern Africa like Harold Wolpe, Martin Legassick, and Giovanni Arrighi developed what came to be known as the subsidy thesis (Arrighi 1970; Wolpe 1972; Legassick 1975). This was the argument that wage laborers in South Africa could be paid below the cost of reproduction because their reproduction was subsidized by non-wage forms of income earned by members of their extended household. The non-wage forms of income in the South African case were typically, but not exclusively, earned in the rural homelands or reserves. This thesis was informed by a conceptualization of labor that connected labor's well-being (and capitalist profits) not only to struggles in the factory and in the labor market, but also to broader networks of non-wage labor, especially those dependent on connections to land in rural areas. It allowed a more nuanced view of labor than a factory or movement level focus could provide. For example, even during a period when Black workers' wages were rising at unprecedented rates, the early 1970s, Wolpe (1972) foresaw a coming crisis of reproduction caused by the deteriorating economic conditions in the rural "homelands" on which wage earners depend for non-wage sources of income.

Like any theoretical or conceptual framework, this attention to the land-labor-livelihood connection shaped the sets of questions that scholars asked about workers in South Africa. Legassick and Wolpe's (1976) article "The Bantustans and Capital Accumulation in South Africa" provides a specific example to consider from the era. The authors contrast the sources of non-wage income that predominate in apartheid South Africa with those found wealthy northern countries. In northern countries, Legassick and Wolpe (1976) argue that the forms of non-wage income that households have access to and its distribution is shaped primarily by welfare state policies. In apartheid South Africa, they argue, since laborers are disproportionately resident in the nominally independent homelands, whose governments have no access to the revenues and assets of the apartheid state, "the physical maintenance of the members of the relative surplus population depends much more crucially on the forms of redistribution of income within the working class as a whole," that is, they go on to say, primarily among extended kinship networks (Legassick and Wolpe 1976:104). And since apartheid state policy put restrictions on both the types of assets Black South Africans could own and how and where they could transfer them, "the struggle over the forms of redistribution (within kinship networks) is an arena of class struggle, in both the cities and the rural areas" (Legassick and Wolpe 1976:105). In order to understand this struggle, and in order to understand the well-being and strength of the working class as a whole, Legassick and Wolpe (1976) argued, scholars had to pay attention to the institutions and networks that shaped redistribution of income, or livelihoods. In the South African case, this meant a specific focus on the rural-urban ties between largely male migratory wage workers in the cities and largely female agricultural and reproductive work in the rural apartheid homelands.

Legassick and Wolpe (1976) were primarily concerned with the role of organized labor in a revolutionary political movement which was gaining strength in the early 1970s. In their conclusion they lay out two scenarios that might take place depending on the forms that redistribution takes in the future. First, they say that existence of broad redistributive networks might create "common interests among large sectors of the African population in resisting the

black workers in "low skill" positions. Black South Africans were also excluded from the state's welfare system and received inferior basic provisions such as schooling and health care. 
commonly experienced and shared effects [of apartheid] on living standards" (1976:105). They were writing just a few years after the first major upsurge of labor action among Black workers and just months after the eruption of the student and township movements in 1976. They posited that the emergence of these broad based movements was driven by the existence of such broadly shared common interests. However, they noted that there was also

the possibility for manifestations of sectional division in the black majority of the working class, through the rupture of redistributive links. Remittances by urban workers to the rural areas might decline or cease. Families in the townships might manifest greater individualisation or ruptures might occur in linkages between the families of workers organized in trade unions or other organizations. (1976: 105)

Their attention to land-labor-livelihood connections led them to argue that to understand not only the well-being of the working class, but the trajectory of labor movements, scholars had to pay attention to remittance flows, family and household structure, and rural-urban linkages.

These are the kinds of questions that the land-labor-livelihood connection guided scholars toward in the 1970s. If labor sociologists of subsequent years had continued to follow the indicators and processes that Legassick and Wolpe (1976) highlighted as important, they would have seen many significant changes. The residency restrictions and job classifications of apartheid have been removed. Social spending in former homelands has increased significantly. Welfare provisions like pensions, public health care, and nearly free primary education have been extended to all South Africans. But many services that were formerly free, such as electricity and water in urban areas, have now been privatized. Unemployment and casualization have risen to among the highest levels in the world. So there are some trends which have transferred the costs of reproduction to the state, but there are others that have increased the burden on workers' own households. Understanding how these changes have affected workers' households, and how households have responded, remains key to understanding the possibilities and constraints facing the labor movement today.

\section{THE PUBLIC TURN IN SOUTH AFRICA: THE LABOR LITERATURE SINCE 1990}

Despite their centrality to the labor literature of the 1970s and 1980s, these issues of LLL connections were, for the most part, absent from central debates of the 1990s and 2000s, the period of the public turn. This section will summarize the central debates of the contemporary labor literature, paying attention to how the focus on movements has shaped the types of questions labor scholars have asked. The paper will then contrast this movement-centered literature with the emerging body of work which returns to the LLL focus of earlier South African work.

In contrast to the United States, the initial public turn in South Africa was not a response to organized labor's eroding power, but an attempt by scholars to explain its dynamism in the 1980s. The concept of social movement unionism was developed in this period to describe the country's vibrant labor movement, whose struggles extended beyond the shop floor to include issues of economic policy and politics. However, despite their resounding success in achieving the political goal of non-racial democracy in the country, South African unions were unable to shield their members and the country's workforce in general from the decreased security of wage work that has defined the South African labor market over the past few decades. During this 


\section{JOURNAL OF WORLD-SYSTEMS RESEARCH}

period, union density has declined while informal labor, casual labor, and unemployment have risen dramatically (Bodipe 2006; Buhlungu 2010: Chapter 4). It is widely recognized by both scholars and unions themselves that uniting formal workers with the insecure majority of the labor force is key to countering the negative effects of neoliberalism on South Africa's workers. ${ }^{5}$ How (and even whether) such an alliance can be achieved has been a central debate among labor scholars over the past two decades.

In the first years after the fall of apartheid there was optimism about the role unions could play in constructing a pro-worker economic policy for the new government. An early expression of this optimism is a widely cited article by Eddie Webster and Glen Adler (1999). The article argued for a strategy that would build upon unions' formal alliances with the governing party to achieve a brokered tripartite class compromise that could lead to job creation and continuing profitability of South Africa capital. The authors recognized that a major obstacle to such a compromise is that unions would have to organize the large parts of the labor force that are unemployed, casually employed, or otherwise unorganized. While there were no prominent examples of such alliances at the time, the authors felt it remained a possibility.

As scholars have attempted to understand how such a broad coalition might be realized, they have turned their attention to analyzing the tactics and strategies of labor unions themselves. A section of the labor literature has examined organizing efforts and new organizational forms that target vulnerable and unorganized workers. One of the most prominent organizations of informal workers in the country has been the Durban-based Self Employed Women's Union (SEWU), which modeled itself on the Self Employed Women's Association of India. Annie Devenish and Caroline Skinner argue that one of SEWU's greatest successes was setting the precedent that it is possible to organize those working the informal economy (2006:273). However, they also note that the union never achieved financial viability, a fact that ultimately led to its dissolution in 2004.

A more successful example of independent organization among informal workers is Sikhula Sonke, a women's farmworker's union based in the winelands of the Western Cape. Fiona White (2010) describes the union's multilevel strategy that includes engaging with employers to challenge unfair labor practices on specific farms and appealing to the government to influence labor market policy that affects all farmworkers. Sikhula Sonke's victories include a first of its kind moratorium on evictions of farm dwellers in their area and influencing the national department of labor to remove the two-tiered minimum wage that set a lower rate for rural workers (White 2010:682-3).

Although unions like SEWU and Sikhula Sonke offer compelling new organizational models, the large amount of attention given to these and a few other modest examples of informal workers' unions is evidence of how few successful examples of such organizations there have been. Initiatives from within existing unions to organize informal workers have been equally limited. Mark Bennett (2003) documents the enormous challenges faced by the South African Clothing and Textile Workers' Union in acting on a conference resolution to organize informal workers in the industry. Challenges include locating informal factories, collecting dues,

\footnotetext{
${ }^{5}$ See for example COSATU's own "Report of the September Commission on the Future of Unions" which argued that if the unions failed to organize vulnerable layers of workers it "would find it mettles to contest market trends toward 'flexibility.' Ultimately, COSATU could end up being based in a shrinking section of the working class, as has happened to trade unions in a number of other countries" (September Commission 1997).
} 
and designing a benefits package to attract membership (Bennett 2003). Bezuidenhout and Buhlungu (2007) discuss the difficulties the National Union of Mineworkers (NUM) has faced in organizing the growing numbers of contract workers in their industry. Not only has the NUM had little success (only 10\% of members are employed by subcontractors) but the presence of large numbers of unorganized contract workers is "creating tensions within the workforce and threatening the solidarity that helped unite mineworkers to confront injustices in mining" (2007:255). Bridget Kenny (2005) describes a similar situation in the retail sector, where unions have been undermined by employers' expanded use of casual and subcontracted workers. However, noting the examples of self-organization among non-union workers that Kenny reports, Karl Von Holdt and Eddie Webster (2008:342) conclude that "union weakness was not inevitable under these conditions, but resulted rather from a failure to adopt innovative and proactive organising strategies."6

While the goal of this "strategies and tactics" literature would seem to be to discover effective measures unions might take to strengthen their positions, it has in fact produced a rather dim view of union "innovation." As Buhlungu (2009) bleakly concludes after a summary of unions' attempts to organize casual and informal workers,

while these efforts are laudable, they are clearly not adequate for the enormous challenges unions face. The restructuring of work that we have witnessed in the last twenty years or so threatens the very existence of trade unionism by fragmenting workings and undermining the basis for solidarity. [Unions' efforts] are doomed to failure as long as they seek to cling to the notion of a unionism based on the full-time permanent worker. (95-6)

Buhlungu's (2009) pessimism is matched by a number of labor scholars who have concluded that unions' decline is not the result of poor strategies or tactics but of a fundamental shift in the class structure which has divided the interests of wage workers from the un- and underemployed majority. Jeremy Seekings and Nicolai Natrass (2005) argue that union members in South Africa have become a labor aristocracy. Analyzing the class structure in post-apartheid South Africa, they conclude that the employed-unemployed divide is the most significant driver of contemporary inequality. They therefore see the labor force as divided into two classes, "insiders" and "outsiders." Seekings and Natrass argue that in this situation the most pro-poor strategy is not to protect wages and working conditions as unions attempt to do, but to expand employment, thereby transferring some outsiders to insider status. In order to do this, they argue, it is necessary to lower wages, which will decrease the quality of the average job available but increase the number of insiders, and therefore lower inequality.

Franco Barchiesi (2007) goes a step further in his pessimism about the jobs crisis in South Africa. He argues that an erosion of the quality of wage labor has even undermined the livelihoods of workers who Seekings and Natrass would consider "insiders." Referring to the declining economic position of the "formal, permanent, mostly unionized" workers he interviewed for his research, Barchiesi (2007: 64) concludes that the "deterioration of their material conditions...confirms a growing body of research according to which, far from being a vehicle of social advancement and emancipation, wage labor is turning in South Africa into a reality of poverty and social exclusion."

\footnotetext{
${ }^{6}$ See Von Holdt and Webster (2008) for a more comprehensive review of the literature on organizing vulnerable workers.
} 


\section{JOURNAL OF WORLD-SYSTEMS RESEARCH}

The scholars who see organized and unorganized workers as in conflict tend to focus on organizing among "outsiders" themselves. South Africa has become a center for research on "new social movements" (NSM) which unite the poor, usually un- or underemployed, around issues of livelihood, such as housing, health care, and service delivery. This NSM literature only rarely engages with or is engaged by the labor literature in South Africa.

The central divide in the literature summarized above can be characterized as one between optimists and pessimists. The optimists continue to see unions as important actors in efforts to realize pro-worker and pro-poor economic policies. They therefore search for the right strategies that will allow unions to regain their strength and to combat the erosion of formal wage work. The pessimists see unions as outdated and as obstacles to realizing pro-poor developmental outcomes. They therefore concentrate on weakening unions or strengthening organizations of non-workers. This literature has arrived at a sort of stalemate. Unions continue to experience declines and have little to show for years of research into "innovative" and "bold" new strategies. Yet they remain the organizations with the most institutional influence who can and do advocate for workers. NSMs, despite their vibrancy, remain issue-based, fragmented and, with a few notable exceptions, unable to achieve the organizational stability required to influence large scale policy shifts.

The South African literature of the 1970s presents a potential model for moving beyond this stalemate. While the current literature has thoroughly examined the effects of wage labor's decline on labor organizations, there has been less focus on how workers, their households, and their livelihoods have been affected. It is noteworthy that both sides of the current debate accept that the erosion of formal wage work and of union membership has meant an erosion and fragmentation of the working class itself. That is, workers are seen as divided into classes of organized-unorganized or insiders-outsiders. Many of those who have fallen out of formal employment and union membership have also fallen out of the analysis of labor scholarship.

If scholars had maintained the South African literature's traditional focus on LLL connections, it would have guided them toward different sets of questions about the effects of formal wage labor's decline. Such a refocusing would push scholars to focus not simply on union strategies or on inequalities between employed and unemployed, but on the redistributive networks that are the core of the labor-livelihood connection. Renewed attention to the laborlivelihood connection would show that the relationship between organized and unorganized members of the labor force is not shaped primarily by strategies of labor organizations, as the optimists seem to assume, nor by their position of individuals vis-a-vis wage labor, as the pessimists argue. This is because the fact remains that, despite the removal of apartheid, individuals' reproduction and well-being is not determined solely by their wages, but by the diverse sources of livelihood that their household and broader social networks connect them to. In order to understand these, scholars interested in South African labor must look empirically to understand, given the decline of formal wage labor and the removal of apartheid legal restrictions on residency, job availability, etc., what has happened materially to the incomes of households and to the economic and social connections that shape the lived reality of South African workers. To determine this, scholars must analyze series of questions which are an updated version of those posed by Legassick and Wolpe in 1976.

Is there still a subsidy of urban workers by rural households and kin? Or has the decline of rural livelihoods meant that the subsidy has reversed directions? Or is there some other form 
of subsidy not connected to land and rural household that is now more significant? Have there been a separation and a differentiation between wage earning households and non-wage earning households? Have households changed form, or increased in size? Have they become more or less geographically dispersed? Etc. These kinds of questions get at the heart of how the end of apartheid has affected the broad livelihood networks which South African labor sociologists of the 1970s argued were essential to understanding the well-being and collective strength of the country's workers.

\section{A RE-EMERGING LITERATURE IN SOUTH AFRICA}

In recent years a growing number of South African labor sociologists have begun to return to these issues. Gillian Hart and Ari Sitas's piece "Beyond the Urban-Rural Divide," cited above, was among the first to argue for the continuing centrality of land-labor-livelihood connections. Von Holdt and Webster (2005:27) have argued that the decline of secure wage labor is playing out as a crisis of social reproduction among South African households. To understand this crisis, they say, scholars must "reconceptualize the meaning of work to include [formal and informal labor] as well as social reproduction in households and communities" (33). A number of scholars working on South and Southern Africa are following the suggestions of these authors, examining the effects of this crisis of reproduction on the households of South African workers.

This emerging body of work demonstrates that the relationship between land, labor, and livelihood remains dynamic and important to understanding the well-being of workers. One of the most prominent examples of this new literature is Eddie Webster, Rob Lambert, and Andries Bezuidenhout's (2008) Grounding Globalization: Labor in the Age of Insecurity. The book compares the experiences of workers in White goods factories in South Africa, Australia and South Korea. The effects of work restructuring are compared not only in the factory and in the labor movement, but in the households of workers in each place.

Sarah Mosoetsa's (2011) Eating from One Pot shows how households in two townships in KwaZulu-Natal province have coped with South Africa's jobs crisis. The townships are sites of factory closings, and residents have dealt with the loss of wage income by relying on social support from households and community associations. However, this has not been a process driven entirely by altruism and reciprocity. Mosoetsa argues that older women, who are the most common recipients of social grants, bear the greatest burden and serve as the "fulcrum on which household survival turns" in the poorest households (1).

This is a finding confirmed by Khayaat Fakier and Jacklyn Cock (2009). Their case study of five townships found that women were increasingly migrating in search of work to replace income lost when male household members became unemployed. Since these migrant women's poor households depend on intense care work for survival, the departure of female migrants places additional burdens on the women who are left behind.

Bruce Frayne (2007) has found that poor households in Namibia's largest city, Windhoek, rely on subsidies from rural households, particularly in the form of food transfers. This is a striking reversal of the typically assumed direction of urban-rural support. Ian Scoones and his collaborators, in their 10 year case study of Zimbabwe's land reform program in the Masvingo province show that land recipients have not become full-time farmers, but many have used their new land as a basis for a diverse portfolio of income and livelihood generating activities, including off-farm employment (Scoones et al. 2010). 


\section{JOURNAL OF WORLD-SYSTEMS RESEARCH}

Even this brief sampling of new literature points to some weakness of the labor movements and movement-centered labor literature. Unions in South Africa (as in much of the world) are dominated by men, particularly at the leadership levels, and the decline of formal wage labor has had the most direct impact on male workers (Buhlungu 2010: 129-132). Yet the emerging LLL literature shows that it is women who have been left with the burden of sustaining livelihoods in the absence of wage income. If unions are to build a broad coalition with the unand underemployed majority, this work suggests it must take up not only issues of wages and working conditions, but issues of gender inequality, policy support for child and elder care, and other issues which affect the women who struggle to support the most vulnerable working class households.

The work of Frayne (2007) and Scoones et al. (2010) highlights the complex and changing relationship between land and wage work. The urban unemployed have increasingly come to rely on rural connections as a support system while they search for work. For employed workers who have experienced a loss of benefits, especially pensions, the ties to land have become an important safety net for periods of unemployment and retirement. Yet, as with gender issues, the labor movement has not engaged with issues of land or migration in its attempt to broaden its coalition.

\section{CONCLUSION}

On the surface, a call for focusing research on households and livelihoods may appear to be a call for a localized and parochial labor studies that analyzes the specificities of workers' lives in each country or region. In fact, a focus on local livelihoods provides labor scholars a path to achieve that holy grail of globally oriented research, connecting the local to the global (and viceversa). Smith and Wallerstein's work on households was informed by the hypothesis that the structure and economic functions of households at a given time is shaped by global economic processes. Specifically they argued that in times of global economic downturns, households would become more important to processes of social reproduction. This proposition has never been fully engaged with by labor scholars, yet it seems to be borne out by the picture that emerges from the new South African literature cited above. Absent a global literature on LLL connections, however, it is difficult to say with confidence which aspects of South Africa's crisis can be combated by unions and movements at the national level and which require a global response.

A global LLL literature would even push beyond the limitations that faced the South African work of the 1970s that this article has presented as a model. That literature connected workers to their households and to the land, but it did not give attention to the global economic processes that shaped the field upon which South African labor struggled. As a result, although South African workers were ultimately able to overthrow apartheid, they did not anticipate the rise of global neoliberalism that redoubled the burdens faced by workers and their households.

Yet a global LLL literature would also be valuable for providing clarity about how local conditions interact with "the global." Unlike the 1970s, labor unions around the world today often see global processes ("globalization," "neoliberalism," etc.) as abstract forces against which their local struggles are powerless. Yet local conditions do make significant differences for workers. For example, Hart (2002: 224-5) has noted the puzzling fact that in 1995 South 
African textile workers' wages were twice as high as their Chinese counterparts, but the Chinese workers' wages provided a higher purchasing power. Hart (2002) finds the explanation in the fact that Taiwanese workers experienced land reform, which provides an almost universal social wage, whereas South African workers have experienced land dispossession, which undermines the ability of households to provide a basic livelihood except through the market. Such contrasts can help point labor unions toward issues that might have broad impacts on workers' well-being, despite the persistent influence of global neoliberalism. In fact, the very local sphere of households and livelihoods might be the most effective level at which unions can combat the global processes that weaken their members and the broader labor force. But such struggles would depend on a labor studies that goes beyond the workplace and beyond the movements to analyze the connections between land, labor, and livelihoods.

\section{REFERENCES}

Arrighi, Giovanni. 1970. "Labor Supplies in Historical Perspective: A Study of the Proletarianization of the African Peasantry in Rhodesia." Journal of Development Studies 6(3): 197-234.

Barchiesi, Franco. 2007. "Wage Labor and Social Citizenship in the Making of PostApartheid South Africa." Journal of Asian and African Studies 42(1): 39-72.

Bennett, Mark. 2003. "Organizing in the Informal Economy: A Case Study of the Clothing Industry in South Africa." SEED Working Paper No. 37. InFocus Programme on Boosting Employment through Small Enterprise. Geneva: International Labor Organization.

Bezuidenhout, Andries. 2000. "Towards Global Social Movement Unionism? Trade Union Responses to Globalization in South Africa," Labour and Society Programme Discussion Paper No. DP/115/2000. International Institute for Labor

Studies. Geneva: International Labour Organisation.

Bezuidenhout, Andries and Sakhela Buhlungu. 2007. "Old Victories, New Struggles: The State of the National Union of Mineworks." Pp. 245-265 in The State of the Nation: South Africa 2007, edited by Sakhela Buhlungu, John Daniel, Roger Southall, and Jessica Lutchamn. Cape Town: Human Science Research Council Press.

Bodipe, Oupa, ed. 2006. The Extent and Effects of Casualisation in Southern Africa: Analysis of Lesotho, Mozambique, South Africa, Swaziland, Zambia and Zimbabwe. Research Report for the Danish Federation of Workers. Johannesburg: NALEDI.

Buhlungu, Sakhela. 2009. "South Africa: The Decline of Labor Studies and the Democratic Transition." Work and Occupations 36: 145-61.

------. 2010. A Paradox of Victory: COSATU and the Democratic Transition in South Africa. Scottsville, South Africa: University of KwaZulu-Natal Press.

Burawoy, Michael. 1976. "The Functions and Reproduction of Migrant Labor: Comparative Material From Southern Africa and the United States." American Journal of Sociology 81(5): 1050-871.

------. 2008. "The Public Turn: From Labor Process to Labor Movement." Work and Occupations 35(4): 371-87. 


\section{JOURNAL OF WORLD-SYSTEMS RESEARCH}

Devenish, Annie and Caroline Skinner. "Collective Action in the Informal Economy: The Case of the Self-Employed Women's Union: 1994-2004" in Voices of Protest: Social Movements in Post-Apartheid South Africa, edited by Richard Ballard, Adam Habib, and Imraan Valodia. Scottsville, South Africa: University of KwaZulu-Natal Press.

Fakier, Khayaat and Jacklyn Cock. 2009. "A Gendered Analysis of the Crisis of Social Reproduction in Contemporary South Africa." International Feminist Journal of Politics 11(3): 353-71.

First, Ruth. 1983. Black Gold: The Mozambican Miner, Proletarian and Peasant. New York: St Martin's Press.

Frayne, Bruce. 2007. "Migration and the Changing Social Economy of Windhoek, Namibia." Development Southern Africa 24(1): 91-108.

Habib, Adam and Imraan Valodia. 2006. "Reconstructing a Social Movement in an Era of Globalisation" in Voices of Protest: Social Movements in Post-Apartheid South Africa, edited by Richard Ballard, Adam Habib, and Imraan Valodia. Scottsville, South Africa: University of KwaZulu-Natal Press.

Hart, Gillian. 2002. Disabling Globalization: Places of Power in Post-Apartheid South Africa. Berkeley: University of California Press.

Hart, Gillian and Ari Sitas. 2004. "Beyond the Urban-Rural Divide: Linking Land, Labour, and Livelihoods." Transformations 56: 31-8.

James, Deborah. 2001. "Land for the Landless: Conflicting Images of Rural and Urban in South Africa's Land Reform Programme." Journal of Contemporary African Studies 19(1): 93109.

Kenny, Bridget. 2005. “The Market Hegemonic Workplace Order in Food Retailing.” Pp. 217242 in Beyond the Apartheid Workplace: Studies in Transition. Scottsville, South Africa: University of KwaZulu-Natal Press.

Legassick, Martin. 1975. "South Africa: Forced Labor, Industrialization, and Racial Differentiation." Pp. 229-270 in The Political Economy of Africa, edited by Richard Harris. New York: John Wiley.

Legassick, Martin and Harold Wolpe. 1976. "The Bantustans and Capital Accumulation in South Africa." Review of African Political Economy 7: 87-107.

Mosoetsa, Sarah. 2011. Eating From One Pot: The Dynamics of Survival in Poor South African Households. Johannesburg: Wits University Press.

Pillay, Devan. 2006. "Cosatu, Alliances and Working-Class Politics.” Pp. 167-198 in Trade Unions and Politics: Cosatu Workers' Political Attitudes in South Africa, edited by Sakhela Buhlungu. Cape Town: Human Sciences Research Council Press.

Scoones, Ian, Nelson Marongwe, Blasio Mavedzenge, Jacob Mahenehene, Felix Murimbarimba, and Chrispen Sukume. 2010. Zimbabwe's Land Reform: Myths and Realities. Johannesburg: Jacana Press.

Seekings, Jeremy and Nicoli Natrass. 2005. Class, Race, and Inequality in South Africa. New Haven, CT: Yale University Press.

Seidman, Gay. 1994. Manufacturing Militance: Workers Movements in Brazil and South Africa, 1970-1985. Berkeley: University of California Press.

September Commission. 1997. Report of the September Commission on the Future of Unions. Johannesburg: COSATU. 
Smith, Joan and Immanuel Wallerstein. 1992. "Households as an Institution of the Worldeconomy." Pp. 3-24 in Creating and Transforming Households: The Constraints of the World-Economy, edited by J. Smith and I. Wallerstein. Cambridge: Cambridge University Press.

Von Holdt, Karl and Edward Webster, eds. 2005. Beyond the Apartheid Workplace: Studies in Transition. Scottsville: University of KwaZulu-Natal Press.

-----. 2008. "Organising the Periphery: New Sources of Power in the South African Workplace." Employee Relations 30 (4):333-354.

Webster, Edward. 2006. "Trade Unions and the Challenge of the Informalisation of Work." Pp. 21-43 in Trade Unions and Politics: Cosatu Workers' Political Attitudes in South Africa, edited by Sakhela Buhlungu. Cape Town: Human Sciences Research Council Press.

Webster, Eddie and Glen Adler. 1999. "Toward a Class Compromise in South Africa's 'Double Transition': Bargained Liberalization and the Consolidation of Democracy." Politics and Society 27: 347-85.

Wolpe, Harold. 1972. "Capitalism and Cheap Labour-Power in South Africa: From Segregation to Apartheid." Economy and Society 1(4): 425-55. 